\section{REFLEKSI HUKUM}

Jurnal Ilmu Hukum
p-ISSN 2541-4984 | e-ISSN 2541-5417

Volume 6 Nomor 1, Oktober 2021, Halaman 19-36

DOI: https://doi.org/10.24246/jrh.2021.v6.i1.p19-36

Open access at: http://ejournal.uksw.edu/refleksihukum

Penerbit: Fakultas Hukum Universitas Kristen Satya Wacana

\title{
PERTANGGUNGJAWABAN PEMEGANG SAHAM PERSEROAN TERBATAS MELALUI INDIKATOR ALTER EGO DALAM PENERAPAN DOKTRIN PCV DI INDONESIA
}

\author{
Gideon Paskha Wardhana \\ Nindyo \& Associates, Attorney at Law and Capital Market Consultant|karelevan@gmail.com
}

\author{
A R T I C L E I N F O \\ Article history: \\ Received \\ 5 Mei 2021 \\ Revised \\ 24 Mei 2021 \\ Accepted \\ 18 Oktober 2021
}

Kata-kata Kunci: Alter ego; Piercing the corporate veil; Pertanggungjawaban pribadi; Pemegang saham; Perseroan terbatas.

\section{Keywords:}

Alter ego; Piercing the corporate veil; Personal liability; Shareholder; Limited company.

\begin{abstract}
Abstrak
Penelitian ini ditujukan guna memahami tujuan dari diadopsinya alter ego sebagai indikator dalam penerapan doktrin piercing the corporate veil (PCV) dan konsep pertanggungjawaban harta pribadi pemegang saham dalam Undang-Undang Nomor 40 Tahun 2007 tentang Perseroan Terbatas (UUPT 2007), serta mengukur efektifitas dari perlindungan hukum yang diberikan melalui penerapan alter ego sebagai indikator doktrin PCV tersebut. Penelitian ini merupakan penelitian yuridis normatif yang dilakukan melalui penelitian kepustakaan dan dianalisa dengan metode penelitian kualitatif atas data sekunder yang ditemukan.

Hasil penelitian menunjukkan bahwa pertanggungjawaban pemegang saham pada suatu PT, hanya terbatas pada sejumlah saham yang mereka miliki. Saat ini, karakteristik pertanggungjawaban terbatas dan badan hukum yang terpisah ini sering disalahgunakan untuk menciptakan tameng bagi para pemegang saham. Guna mencegah praktek yang menyimpang ini, doktrin PCV telah diadopsi oleh UUPT 2007. Namun demikian, doktrin PCV tersebut hanya diadopsi secara setengah-setengah. Begitu pula dengan alter ego sebagai indikator yang mana penerapannya tidak efektif dan jarang digunakan.
\end{abstract}

\section{Abstract}

This research aims to understand the purpose of the adaption of the alter ego as an indicator to the doctrine of piercing the corporate veil (PCV) and the concept of personal liability in Act No. 40 of 2007 on Limited Liability Company (LLA 2007). In addition, this research will evaluate the effectiveness of the legal protection that is given through the implementation of the alter ego. This juridical and normative research uses literature and qualitative research method on the secondary resources. The research result shows that the responsibility of shareholders in a limited company (PT) is limited to the number of shares they have in the company. Currently, this characteristic of limited liability and separate legal entities is often misused to create a shield for shareholders so that they can avoid being personally liable for their illegal acts. To prevent this deviant practice, the PCV doctrine, which acts as an exception to the principle of limited liability, has been adopted by the LLA 2017. However, the PCV doctrine is only partially adopted. Likewise with the alter ego is an indicator, which is ineffective and rarely used. 


\section{PENDAHULUAN}

Perseroan merupakan artificial person, yang tidak memiliki wujud (intangible), keinginan (will), realitas yang substansial (substantial reality), yang lahir karena hukum. ${ }^{1}$ Perseroan sebagai perusahaan bisnis sedikitnya memiliki lima karakteristik struktural, yaitu: (1) legal personality (badan hukum), (2) limited liability (tanggung jawab terbatas); (3) transferable shares (saham dapat dialihkan); (4) centralized management (manajemen terpusat); dan (5) shared ownership (pemilikan saham oleh pemasuk modal). ${ }^{2}$ Oleh karenanya perseroan adalah sebuah legal person, yang karenanya memiliki kedudukan, hak, dan tanggung jawab hukum yang sebagaimana layaknya natural person tetapi perseroan merupakan entitas hukum terpisah dari direktur dan pemegang sahamnya. ${ }^{3}$ Ditilik dari sejarahnya, menurut Pasal 40 ayat (1) Kitab Undang-Undang Hukum Dagang, selanjutnya disingkat KUHD, bahwa perseroan terdiri dari saham-saham atas nama atau blangko, yang juga disebut saham atas tunjuk atau atas pembawa, dan ayat (2) menentukan bahwa tanggung jawab tiap pemegang saham terbatas pada jumlah nominal dari saham-saham yang dimilikinya. ${ }^{4}$

Modal sebagai bagian dari harta kekayaan perseroan terdiri dari modal perseroan atau modal dasar, yaitu modal yang dijanjikan akan ditempatkan atau diambil oleh calon pemegang saham atau pendiri dan modal yang disetor, yaitu modal yang benar-benar secara riil telah disetor ke kas perseroan. Memasukkan modal ke dalam perseroan berarti pendiri atau pemilik modal akan bertransformasi menjadi pemilik atau pemegang saham, yang mana tanggung jawab dari pemegang saham hanya terbatas pada saham yang dimilikinya. ${ }^{5}$ Dalam konteks ini, jika tindakan yang diambil perusahaan melalui direkturnya atau atas kendali dan perintah pemegang saham, membawa kerugian bagi perusahaan atau terdapat perjanjian yang menimbulkan kewajiban bagi perusahaan, kalaupun pemegang saham harus ikut bertanggung jawab, maka pertanggungjawaban tersebut terbatas pada sahamnya. ${ }^{6}$ Meskipun demikian, dalam perkembangannya, sejak lahirnya Undang-Undang Nomor 1 Tahun 1995 tentang Perseroan Terbatas, selanjutnya disingkat UUPT 1995, sebagai pengganti Pasal 36 sampai dengan Pasal 55 KUHD yang mengatur tentang perseroan di Indonesia, sampai dengan digantinya UUPT 1995 dengan Undang-Undang Nomor 40 Tahun 2007 tentang Perseroan Terbatas, selanjutnya disingkat UUPT 2007, prinsip pertanggungjawaban pemegang saham terbatas pada saham yang dimilikinya menjadi tidak mutlak. ${ }^{7}$ Pertanggungjawaban pemegang saham pada dasarnya terbatas pada saham yang dimilikinya, diterobos dengan diadposinya doktrin Piercing the Corporate Veil, sebagaimana tersurat

Ben Pettet, Company Law (Pearson Education Limited 2005) 68.

Henry Hansmann, et al., 'what is: Corporate Law?' in Reiner Kraakman, et al., The Anatomy of Corporate Law A Comparative and Functional Approach (Oxford University Press New York 2004) 1.

Adolf A. Berle Jr, 'The Theory of Enterprise Entity’ (1947) 47 (3) Columbia Law Review 343.

Pasal 40 ayat (1) Kitab Undang-Undang Hukum Dagang: "Modal perseroan dibagi atas sahamsaham atau sero-seri atas nama atau blangko. Para persero atau pemegang saham atau sero tidak bertanggung jawab lebih daripada jumlah penuh saham-saham itu."

5 Gideon Paskha Wardhana, 'Pertanggungjawaban Harta Pribadi Pemegang Saham Perseroan Terbatas di Indonesia' (2019) 12 (1) Arena Hukum 3.

Stacey Hunt, 'Piercing The Corporate Veil' (1995) 13 (2) Paralegal Today 68.

Wardhana (n 5). 
dalam Pasal 3 ayat (2) UUPT 1995 maupun UUPT 2007. Ini bermakna bahwa tanggung jawab pemegang saham yang terbatas pada saham yang dimilikinya menjadi tidak terbatas apabila dapat dibuktikan bahwa telah terjadi perbauran harta kekayaan pribadi pemegang saham dengan harta kekayaan perseroan. Artinya, pemegang saham ikut bertanggung jawab secara pribadi terhadap kerugian perseroan, tidak lagi sebatas saham yang dimilikinya dalam perseroan saja sebagaimana prinsip pertanggungjawaban yang dianut sebuah badan hukum. 8

Doktrin Piercing the Corporate Veil (PCV) berlaku apabila pemegang saham tersebut melakukan tindakan-tindakan, seperti memanfaatkan perseroan untuk kepentingan pribadi, terlibat dalam perbuatan melawan hukum yang dilakukan oleh perseroan, atau secara langsung atau tidak langsung melawan hukum menggunakan kekayaan perseroan, yang mengakibatkan kekayaan perseroan menjadi tidak cukup untuk melunasi hutang perseroan. ${ }^{9}$ Salah satunya, PCV dapat muncul apabila pemegang saham yang merupakan bagian dari perseroan, menganggap dirinya sebagai pemilik, atau melakukan fraud dengan menjadikan perseroan tersebut sebagai alter ego nya. ${ }^{10}$ Maksudnya, pemegang saham mengambil kontrol terlalu jauh untuk memperalat perseroan untuk kepentingan dirinya yang mana telah membuat perseroan yang diperalat itu sebagai alter ego atau diri lain (other self) untuk tujuan yang tidak wajar (improper purpose). ${ }^{11}$ Apabila alter ego ini terbukti, maka tanggung jawab pemegang saham yang terbatas tersebut hapus dan berlaku Pasal 3 ayat (2) UUPT 2007 yang mengakibatkan pemegang saham tidak lagi bertanggung jawab secara terbatas. ${ }^{12}$ Permasalahan yang akan dibahas adalah bagaimana pengaturan Alter Ego sebagai indikator dalam penerapan doktrin PCV dalam UUPT? Bagaimana penerapan Alter Ego sehubungan dengan pertangunggjawaban pemegang saham dalam Perseroan Terbatas (PT)? Bagaimana apabila pemegang saham terbukti melakukan alter ego, namun saat terbukti yang bersangkutan sudah bukan merupakan pemegang saham. Sebelum masuk kepada inti pembahasan, akan dibahas terlebih dahulu terkait eksistensi PT sebagai badan hukum untuk dapat lebih memahami pengaturan terkait Perseroan Terbatas.

Penelitian ini merupakan penelitian yuridis normatif yang dilakukan melalui penelitian kepustakaan dan dianalisa dengan metode penelitian kualitatif, dengan mengolah dan menganalisis data-data yang terkumpul menjadi data yang sistematik dan teratur. Secara normatif, penelitian ini dilakukan dengan pendekatan filosofis, pendekatan konsep, dan pendekatan undang-undang. Dengan demikian, penelitian ini diharapkan dapat menjadi sebuah kajian yang bersifat komprehensif dan holistik.

\footnotetext{
$8 \quad$ Kurniawan, 'Tanggung jawab Pemegang Saham Perseroan Terbatas Menurut Hukum Positif' (2014) 26 (1) Mimbar Hukum 70, 71.

9 Vide Pasal 3 ayat (2) Undang-Undang Nomor 40 Tahun 2007 tentang Perseroan Terbatas. Shareholders and Their Responsibilities According to the 'Piercing the Corporate Veil' Doctrine in Indonesia' (2000) 11 (8) International Journal of Innovation, Creativity, and Change 60, 61.

11 Ridwan Khairandy, Perseroan Terbatas Doktrin, Peraturan Perundang-undangan, dan Yurisprudensi (ed. Revisi, Kreasi Total Media Yogyakarta 2009) 270.

Sefriani, 'Status Hukum Aset Perusahaan Negara Dalam Hukum Internasional' (2012) 24 (3) Mimbar Hukum 515, 522.
} 


\section{PEMBAHASAN}

\section{Perseroan Terbatas Sebagai Badan Hukum}

Badan hukum dinyatakan sebagai subjek hukum sejak disahkannya badan hukum tersebut oleh Menteri Hukum dan Hak Asasi Manusia, yang memberikan hak-hak, kewajiban dan harta kekayaan sendiri bagi badan hukum tersebut, terlepas dari hak-hak dan kewajiban-kewajiban serta harta kekayaan para pendiri, pemegang saham, maupun para pengurusnya dan berakhir sebagaimana tertuang dalam Anggaran Dasar serta Akta Pendirian badan hukum tersebut. ${ }^{13}$ PT merupakan salah satu badan hukum yang diatur dalam UUPT. UUPT sendiri tidak menjelaskan apa yang dimaksud dengan badan hukum, walaupun Pasal 1 angka 1 UUPT 2007 menyebutkan bahwa, "Perseroan Terbatas selanjutnya disebut Perseroan adalah badan hukum. ${ }^{14}$

Perseroan merujuk pada modal PT yang terdiri atas sero-sero atau sahamsaham. Adapun kata terbatas merujuk pada tanggung jawab pemegang saham yang luasnya hanya terbatas pada nilai nomial semua saham yang dimilikinya. ${ }^{15}$ Selanjutnya, pengertian PT sebagaimana termaktub dalam Pasal 1 angka 1 UUPT 2007, yaitu "Perseroan Terbatas yang selanjutnya disebut Perseroan, adalah badan hukum yang merupakan persekutuan modal, didirikan berdasarkan perjanjian, melakukan kegiatan usaha dengan modal dasar yang seluruhnya terbagi dalam saham dan memenuhi persyaratan yang ditetapkan dalam undang-undang ini serta peraturan pelaksanaannya." 16 Berdasarkan definisi tersebut, dapat kita cermati bahwa suatu perseroan harus memiliki 3 (tiga) unsur dasar yang terlebih dahulu harus dipenuhi oleh para pendiri PT sebelum dapat mengajukan permohonan kepada Menteri untuk memperoleh statusnya sebagai badan hukum, yaitu sebagai berikut: ${ }^{17}$

1. Perseroan sebagai Persekutuan Modal

Modal dasar perseroan terbagi dalam saham. Rochmat Soemitro menyebutnya sebagai modal saham atau modal sero, atau di dalam Bahasa Belanda disebut maatschapelijk kapitaal atau statutaire kapitaal, yaitu jumlah modal yang disebut dalam akta pendirian, merupakan suatu jumlah maksimum sampai jumlah mana dapat dikeluarkan jumlah surat-surat saham. ${ }^{18}$ Perlu diketahui bahwa modal perseroan hanyalah sebagian dari harta kekayaan Perseroan. Terkait hal ini, Nindyo Pramono berpendapat bahwa harta kekayaan PT itu selalu berubah sejalan dengan gerak usaha PT, sedangkan modal perseroan itu bersifat relatif tetap. ${ }^{19}$ Bahkan untuk setiap perubahan modal perseroan, UUPT 2007 mewajibkan

13 Verti Tri Wahyuni, 'Kepemilikan Tunggal Badan Hukum Perseroan Terbatas' (2017) 8 (2) Jurnal Hukum Novelty 201, 202.

14 Herlien Budiono, 'Arah Pengaturan Undang-Undang Nomor 40 Tahun 2007 tentang Perseroan Terbatas Dalam Menghadapi Era Global' (2012) 1 (2) Junral RechtsVinding 187, 189.

15 Ridwan Khairandy, 'Perseroan Terbatas Sebagai Badan Hukum' (2007) 26 (3) Jurnal Hukum Bisnis 5.

16 Vide Pasal 1 angkat 1 Undang-Undang Nomor 40 Tahun 2007 tentang Perseroan Terbatas. Wardhana (n 5) 5.

Rochmat Soemitro, Penuntun Perseroan Terbatas Dengan Undang-Undang Pajak Perseroan (cet 6, Eresco Jakarta 1979) 99.

19 Nindyo Pramono, Hukum PT Go Public dan Pasar Modal (Andi Offset Yogyakarta 2013) 75. 
perubahan tersebut dilakukan dengan akta notarial dan harus dimohonkan pengesahan kepada Menteri. 20

2. Perseroan Didirikan Berdasarkan Perjanjian

Perseroan didirikan berdasarkan perjanjian artinya pendirian perseroan bersifat kontraktual (contractual, by contract), yakni berdirinya perseroan merupakan akibat yang lahir dari perjanjian. Selain bersifat kontraktual, juga bersifat konsensual (consensual) berupa adanya kesepakatan untuk mengikat perjanjian mendirikan perseroan. ${ }^{21}$ Suatu perseroan didirikan berdasarkan perjanjian dipertegas dalam Pasal 7 ayat (1) UUPT 2007, yang menyatakan bahwa: "Perseroan didirikan oleh 2 (dua) orang atau lebih dengan akta notaris yang dibuat dalam bahasa Indonesia."

Berdasarkan pasal di atas dapat disimpulkan, terdapat dua syarat yang harus dipenuhi untuk mendirikan PT, yaitu (1) Syarat subjektif, minimal ada 2 (dua) orang yang mendirikan perseroan, yang mana yang dimaksud dengan orang juga termasuk badan hukum, sehingga, diperbolehkan apabila ada 2 (dua) PT akan mendirikan PT baru, karena memenuhi unsur dua orang tersebut, (2) Syarat objektif, pendirian perseroan harus dibuat dengan akta notaris yang mana dibuat dalam bahasa Indonesia. 22

Dalam hal ini, Nindyo Pramono berpendapat bahwa UUPT menganut sistem tertutup, artinya bahwa tentang, ada, lahir, atau berdirinya suatu PT tidak dapat dengan jalan lain selain yang ditentukan dalam UUPT. ${ }^{23}$ Dengan demikian, dikarenakan UUPT merupakan bagian dari hukum perdata khusus, maka dengan menganut paham atau doktrin perjanjian, pendirian PT harus pula mengikuti unsur-unsur, asas-asas maupun syarat sahnya suatu perjanjian sebagaimana diatur dalam Buku III KUHPerdata. ${ }^{24}$ Ketentuan yang mendasari tentang syarat sahnya perjanjian dapat kita lihat pada Pasal 1320 KUHPerdata yang menyatakan sebagai berikut:25 "Untuk sahnya suatu perjanjian diperlukan empat syarat:

1) Sepakat mereka yang mengikatkan dirinya (overeenkomst);

2) Kecakapan untuk membuat suatu perikatan (bevoegdheid);

3) Suatu hal tertentu (bepalde onderwerp);

4) Suatu sebab yang halal (geoorloofde oorzaak).

Apabila telah memenuhi keempat syarat tersebut, maka berdasarkan Pasal 1338 KUHPerdata, perjanjian yang disepakati guna pendirian PT menjadi berlaku mengikat sebagai undang-undang bagi para pendiri PT tersebut. 26

\section{Perseroan Melakukan Kegiatan Usaha}

Perseroan melakukan kegiatan usaha dalam bidang perekonomian untuk mendapatkan laba atau keuntungan. Agar kegiatan usaha perusahaan itu sah maka harus mendapatkan izin usaha dari pihak yang berwenang dan harus didaftarkan menurut ketentuan peraturan perundang-undangan. Pasal 2 UUPT 2007 menyatakan bahwa perseroan harus mempunyai maksud dan tujuan serta

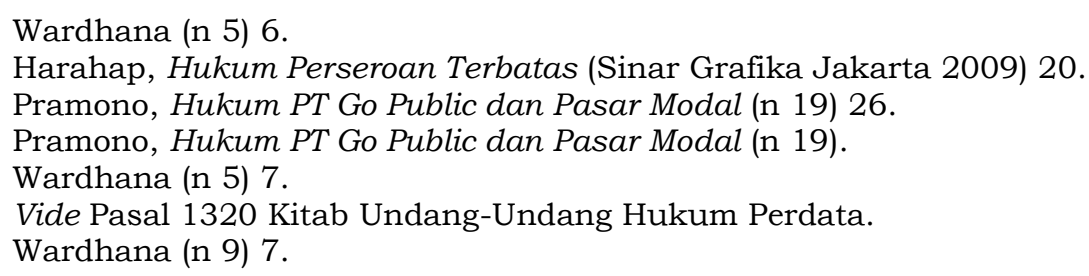


kegiatan usaha yang tidak bertentangan dengan ketentuan perundang-undangan, ketertiban umum, dan/atau kesusilaan. ${ }^{27}$ Selanjutnya, berdasarkan Pasal 18 UUPT 2007, maksud dan tujuan serta kegiatan usaha tersebut harus dicantumkan dalam Anggaran Dasar Perseroan ${ }^{28}$, yang mana dijelaskan lebih lanjut dalam Penjelasan Pasal 18 tersebut, yaitu maksud dan tujuan merupakan usaha pokok perseroan, sedangkan kegiatan usaha adalah kegiatan yang dijalankan guna mencapai maksud dan tujuan perseroan tersebut, yang harus secara jelas dalam Anggaran Dasar, dan rincian tersebut tidak boleh bertentangan dengan Anggaran Dasar. 29

Apabila suatu perseroan sudah tidak mempunyai kegiatan usaha lagi, maka berdasarkan Pasal 142 ayat (1) huruf a jo Pasal 142 ayat (3) UUPT 2007, seharusnya perseroan tersebut dapat dilikuidasi atau dibubarkan dengan keputusan RUPS oleh para pemegang saham, maupun berdasarkan putusan pengadilan sebagaimana terdapat pada Pasal 142 ayat (1) huruf c jo Pasal 146 UUPT 2007. Rudhi Prasetya menyebut perseroan yang sudah tidak mempunyai kegiatan usaha lagi sebagai "PT Kosong", yaitu PT yang sudah tidak menjalankan kegiatan lagi yang pasiva dan aktivanya sudah dalam keadaan nihil. ${ }^{30}$

Berdasarkan Pasal 7 ayat (4) UUPT 2007 menyatakan bahwa Perseroan memperoleh status badan hukum pada tanggal diterbitkannya keputusan Menteri mengenai pengesahan badan hukum Perseroan. ${ }^{31}$ Jadi, meskipun ketiga unsur diatas telah terpenuhi, Perseroan belum memperoleh status badan hukumnya (rechtpersoon) apabila belum diterbitkannya keputusan Menteri tersebut. Dengan demikian, keputusan Menteri tersebut menjadi syarat mutlak yang menandai lahirnya perseroan sebagai badan hukum mandiri (separate legal entity). ${ }^{32}$ Setelah perseroan tersebut memperoleh status badan hukum, dapat diartikan bahwa perseroan tersebut sudah menjadi subjek hukum, yang mempunyai hak dan kewajiban dalam melakukan perbuatan-perbuatan hukum, seperti layaknya seorang manusia. Perseroan tersebut mempunyai kekayaan sendiri, dan ikut serta dalam lalu lintas hukum dengan perantara pengurusnya. Perseroan tersebut pun dapat digugat dan juga menggugat di muka pengadilan. ${ }^{33}$ Keberadaan perseroan sebagai badan hukum dibuktikan dengan Akta Pendirian PT yang mencakup Anggaran Dasar PT yang telah mendapat pengesahan oleh menteri. Dengan pengesahan tersebut, maka perseroan pun telah menjadi subjek hukum korporasi. ${ }^{34}$

\section{Alter Ego Sebagai Indikator Dalam Penerapan Doktrin PCV Dalam UUPT}

Setelah perseroan dinyatakan lahir sebagai badan hukum, maka selubung perseroan atau corporate veil menjadi eksis di mata hukum, dan sekaligus, tanggung jawab pemegang saham pun menjadi nyata adanya. ${ }^{35}$ Limited liability

Vide Pasal 2 Undang-Undang Nomor 40 Tahun 2007 tentang Perseroan Terbatas.

Vide Pasal 18 Undang-Undang Nomor 40 Tahun 2007 tentang Perseroan Terbatas.

Vide Penjelasan Pasal 18 Undang-Undang Nomor 40 Tahun 2007 tentang Perseroan Terbatas.

Rudhi Prasetya, Perseroan Terbatas: Teori dan Praktik (Sinar Grafika Jakarta 2011) 67.

Vide Pasal 7 ayat (4) Undang-Undang Nomor 40 Tahun 2007 tentang Perseroan Terbatas.

Wardhana (n 5) 9.

Simanjuntak, Hukum Perdata Indonesia (Kencana Jakarta 2015) 25.

Wardhana (n 5) 8.

Ibid. 
atau tanggung jawab terbatas adalah suatu kondisi dimana pemegang saham atau shareholder dari suatu perseroan hanya bertanggung jawab sebatas pada sejumlah saham yang mereka miliki di perseroan tersebut. ${ }^{36}$ Secara prinsip, doktrin PCV merupakan ajaran yang berkembang dalam tradisi common law di Inggris sejak 122 tahun silam. Dalam tradisi common law, pemegang saham sebuah perusahaan dibebaskan dari pertanggungjawaban pribadi atas kewajiban perusahaan (corporate veil) ${ }^{37}$

Sebelumnya, apabila dilihat dari prinsip efesiensi ekonomi, terdapat lima alasan mengapa suatu perseroan diberikan tanggung jawab terbatas. ${ }^{38}$ Pertama, pertanggungjawaban terbatas ada untuk membantu pemegang saham dalam mengamati para organ pada suatu perseroan dalam hal mereka berinvestasi karena konsekuensi finansial dari kegagalan perusahaan yang terbatas. Potensi biaya operasional perseroan berkurang karena pertanggung-jawaban terbatas membuat diversifikasi dan kepasifan pemegang saham menjadi strategi yang lebih rasional. ${ }^{39}$

Kedua, pertanggungjawaban terbatas menyediakan insentif bagi para organ perseroan untuk bertindak lebih efisien dan untuk kepentingan pemegang saham dengan mempromosikan transfer bebas saham. Argumen ini memiliki dua bagian. Bagian pertama, bebas transfer saham dipromosikan oleh pertanggungjawaban terbatas karena berdasarkan prinsip ini, kekayaan dari pemegang saham yang lain tidak relevan. Apabila prinsip dari pertanggungjawaban tidak terbatas diberlakukan, nilai saham akan ditentukan sebagian oleh kekayaan pemegang saham. Dengan kata lain, harga dimana pemegang saham individu dapat membeli saham akan ditentukan sebagian oleh kekayaan pemegang saham yang sekarang beresiko karena tanggung jawab yang tidak terbatas. Bagian kedua dari argument ini (pertanggungjawaban terbatas memberi para organ perseroan insentif untuk bertindak lebih efesien dan dalam kepentingan pemegang saham) adalah berasal dari fakta bahwa apabila suatu perseroan diatur dengan tidak efesien, pemegang saham diharapkan bisa menjual saham mereka dengan potongan harga, yang mana hal ini tidak akan terjadi apabila perseroan tersebut dikelola secara efisien. Ini menciptakan suatu kemungkinan terjadinya pengambilalihan perseroan dan pergantian dari para organ yang menjabat. 40

Ketiga, pertanggungjawaban terbatas membantu pengoperasian yang efisien pada pasar sekuritas, karena seperti yang dijelaskan pada paragraf sebelumnya. Harga perdagangan saham tidak akan tergantung pada evaluasi kekayaan pemegang saham secara individu. ${ }^{41}$

Keempat, pertanggungjawaban terbatas mengizinkan diverifikasi efisien oleh pemegang saham, yang mana pemegang saham memungkinkan untuk mengurangi resiko individu mereka. Apabila prinsip pertanggungjawaban tidak terbatas diberlakukan maka para pemegang saham akan kehilangan seluruh kekayaannya

\footnotetext{
36 Nindyo Pramono, 'Perbandingan Perseroan Terbatas di Beberapa Negara' (Karya Ilmiah Badan Pembinaan Hukum Nasional Kementerian Hukum dan Hak Asasi Manusia, November 2012) 19 < https://www.bphn.go.id/data/documents/pk-2012-1.pdf > diakses pada 14 Desember 2020. Milton Bordwin, 'Piercing the Corporate Veil' (1995) 84 (8) Management Review 37. F. Easerbrook and D. Fischel, The Economic Structure of Corporate Law (Harvard University Press, United States 1991) 41-44.

Ibid.

Ibid.

Ibid.
} 
dengan alasan kegagalan dari perseroan. Oleh karena itu, pemegang saham akan mendapat insentif untuk mengurangi jumlah saham yang dimiliki oleh perseroan lain dan bersikeras mendapatkan keuntungan yang lebih tinggi dari investasi mereka karena resiko tinggi yang mereka hadapi. Pertanggungjawaban terbatas tidak hanya memungkinkan disverifikasi namun juga mengizinkan perseroan untuk mendapatkan modal dari biaya rendah karena berkurangnya resiko yang dihadapi oleh pemegang saham. ${ }^{42}$

Kelima, pertanggungjawaban terbatas memfasilitasi keputusan investasi yang optimal oleh para organ. Seperti yang kita lihat, pertanggungjawaban terbatas memberi insentif untuk pemegang saham untuk memiliki portofolio yang beragam. Dalam keadaan seperti itu, para organ harus menginvestasikan proyek dengan nilai bersih terkini, dan dapat melakukannya tanpa mengekspos hilangnya kekayaan pribadi pemegang saham tersebut. Namun, apabila prinsip pertanggungjawaban tidak terbatas diberlakukan, para organ mungkin menolak beberapa investasi dengan nilai positif terkini dengan alasan bahwa dengan demikian resiko bagi pemegang saham akan berkurang. 43

Tanggung jawab pemegang saham dalam Perseroan diatur lebih rinci dalam Pasal 3 ayat (1) UUPT 2007, yang menyebutkan bahwa pemegang saham perseroan tidak bertanggung jawab secara pribadi atas perikatan yang dibuat atas nama perseroan dan tidak bertanggung jawab atas kerugian perseroan melebihi nilai saham yang telah diambilnya. Berdasarkan pasal tersebut, dapat dilihat bahwa pemegang saham hanya bertanggung jawab terbatas pada saham yang dimilikinya saja. Arti dari pertanggungjawaban dalam hal ini adalah terkait dengan akibat perbuatan hukum perseroan terhadap pihak ketiga, dimana apabila terjadi hutang atau kerugian-kerugian, maka hutang itu akan semata-mata dibayar secukupnya dari harta kekayaan yang tersedia dalam perseroan tersebut, sehingga para pemegang saham secara pasti tidak akan memikul kerugian hutang itu lebih dari bagian harta kekayaannya yang tertanam dalam Perseroan. ${ }^{44}$ Terkait dengan hal ini perlu ditekankan bahwa ketentuan mengenai prinsip limited liability pada Pasal 3 ayat (1) UUPT 2007 bersifat residual. Maksudnya, tanggung jawab hukum pemegang saham timbul, ketika perseroan tidak mampu lagi memenuhi beban tanggung jawab kepada pihak ketiga. Sepanjang perseroan mampu menyelesaikan tanggung jawab hukumnya, maka pemegang saham perseroan tidak perlu menanggung beban tanggung jawab hukum perseroan walaupun hanya sebesar setoran atas sahamnya. ${ }^{45}$ Penerapan konsep pertanggungjawaban di atas sebenarnya lebih merupakan konsekuensi dari badan hukum PT tersebut. Pasal 1 angka 1 UUPT 2007 menyatakan bahwa PT adalah badan hukum yang merupakan persekutuan modal, didirikan berdasarkan perjanjian, melakukan kegiatan usaha dengan modal dasar yang seluruhnya terbagi dalam saham dan memenuhi persyaratan yang ditetapkan dalam undang-undang ini serta peraturan pelaksanaannya. Definisi ini menyiratkan bahwa perseroan merupakan suatu

Ibid.

Ibid.

Rudhi Prasetya, Kedudukan Mandiri dan Pertanggungjawaban Terbatas Dari Perseroan Terbatas (Airlangga University Press Surabaya 1983) 13.

45 Sulistiowati, 'Doktrin-Doktrin Hukum Mengenai Tanggung Jawab Hukum dalam Perusahaan Grup' (2012) 31 (3) Hukum Bisnis 12. 
entitas hukum yang terpisah dari pemegang saham sekaligus direktur dan komisaris perseroan tersebut. 46

Prinsip limited liability yang memberikan perlindungan kepada pemegang saham dapat mendorong munculnya sikap oportunistik dari pemegang saham untuk memanfaatkan badan hukum perseroan bagi kepentingan pribadi pemegang saham. Karena pada kenyataannya perlindungan hukum ini telah menimbulkan moral hazard di mana pemegang saham suatu perseroan menyalahgunakan prinsip pembatasan tanggung jawab untuk kepentingan pribadi mereka. Misalnya dengan mendirikan perseroan yang pada hakikatnya hanya bertindak sebagai buffer atau perisai agar seorang pemegang saham dapat melakukan perbuatan melawan hukum, menghindari kewajiban hukum, atau melakukan kegiatan bisnis berisiko tinggi tanpa perlu khawatir akan dimintakan pertanggungjawaban pribadi. ${ }^{47}$

Terhadap dimungkinkannya penyalahgunaan limited liability oleh pemegang saham atau untuk menghindari munculnya hasil yang tidak diharapkan dari berlakunya limited liability, UUPT 1995 dan UUPT 2007 telah memuat adanya pengaturan pengecualian ${ }^{48}$, yaitu diatur pada Pasal 3 ayat (2) UUPT 2007, yang mana telah mengatur mengenai hapusnya tanggung jawab terbatas dari pemegang saham terhadap tanggung jawab hukum suatu perseroan. Ketentuan ini merupakan penerapan dari doktrin PCV. Sesuai dengan peruntukkannya UUPT 2007 sebagai kerangka pengaturan bagi perseroan tunggal, Pasal 3 ayat (2) dan Pasal 7 ayat (5) dan (6) UUPT 2007 mengatur bahwa alasan timbulnya PCV pada pemegang saham perseroan disebabkan apabila:

1. Ketidak-lengkapan syarat perusahaan sebagai badan hukum;

2. Itikad buruk pemegang saham dalam memanfaatkan perusahaan bagi kepentingan pribadi;

3. Pemegang saham terlibat dalam perbuatan melawan hukum;

4. Pemegang saham menggunakan asset perseroan sehingga perusahaan tidak dapat melunasi hutangnya;

5. Tidak dipenuhinya syarat minimal dua pemegang saham dalam waktu enam bulan setelah berubahnya komposisi pemegang saham.

Selanjutnya, dalam Memori Penjelasan Pasal 3 ayat (2) UUPT 2007, menyatakan bahwa dalam hal-hal tertentu tidak tertutup kemungkinan terhapusnya tanggung jawab terbatas tersebut apabila terbukti terjadi hal-hal yang disebutkan dalam ayat ini. Tanggung jawab pemegang saham sebesar setoran atas seluruh saham yang dimilikinya kemungkinan hapus apabila terbukti, antara lain terjadi pencampuran harta kekayaan pribadi pemegang saham dan harta kekayaan pribadi perseroan sehingga perseroan didirikan semata-mata sebagai alat yang dipergunakan oleh pemegang saham untuk memenuhi tujuan pribadinya. ${ }^{49}$ Pengaturan tersebut pun sejalan dengan Pasal 1365 Kitab Undang-Undang Hukum Perdata, yang menyatakan bahwa tiap perbuatan yang melanggar hukum dan membawa kerugian kepada orang lain, mewajibkan orang yang menimbulkan kerugian itu karena kesalahannya untuk menggantikan kerugian tersebut.

\footnotetext{
46 Yafet YW Rissy, 'Doktrin Piercing the Corporate Veil: Ketentuan dan Penerapannya di Inggris, Australia, dan Indonesia' (2019) 4 (1) Refleksi Hukum: Jurnal Ilmu Hukum 13.

Sulistiowati (n 45) 24.

Ibid, 28.

Ibid.
} 
Pemegang saham dapat bertanggung jawab sampai dengan harta pribadinya apabila pemegang saham tersebut terbukti melakukan tindakan sebagaimana tercantum dalam Pasal 3 ayat (2) UUPT 2007. PCV sendiri dapat dibuktikan melalui beberapa indikator, salah satunya yaitu alter ego. Menurut Fredrick J. Powell, alter ego sangat sering digunakan untuk memberlakukan pengecualian terhadap PCV dengan melakukan dua sampai tiga tes dan memenuhi tes tersebut. ${ }^{50}$ Di United States, alter ego biasa digunakan untuk menentukan apakah anak perusahaan berfungsi sebagai fasad untuk induk perusahaan, atau dengan kata lain, apakah bisnis yang dijalankan oleh anak perusahaan merupakan alter ego dari induk perusahaan. Fredrik J. Powel berpendapat bahwa hal tersebut terjadi karena induk perusahaan merupakan pemegang saham mayoritas dari anak perusahaan, cakupan induk perusahaan dalam membiayai kegiatan bisnis anak perusahaan, atau kegiatan bisnis yang dilakukan oleh induk perusahaan dan anak perusahaan merupakan kegiatan bisnis yang sama, dimana anak perusahaan hanya mensupport kegiatan bisnis induk perusahaan. Semakin besar persentase saham yang dimiliki oleh induk perusahaan, semakin menunjuk ke arah alter ego. ${ }^{51}$ Seperti yang disebutkan sebelumnya, alter ego terjadi disaat pemegang saham merasa perseroan tersebut merupakan miliknya, dan menjalankan perseroan untuk kepentingan pribadinya. Selain itu, alter ego dapat dibuktikan dengan melihat apakah pemegang saham melakukan fraud kepada pihak ketiga dan melihat apakah pihak ketiga mengalami kerugian sebagai hasil dari induk perusahaan menggunakan anak perusahaannya. 52

Penerapan PCV juga dapat dilihat dari keadaan tidak wajar yang dilakukan oleh perseroan, hasil dari menjadikan perseroan tersebut sebagai alter ego dari pemegang saham. Beberapa keadaan tidak wajar tersebut, yaitu pertama, pihak ketiga ditipu saat melakukan transaksi dengan perseroan, bisnis dari perseroan tersebut membingungkan, modal perseroan tidak disebutkan dengan benar atau tidak dibayarkan, jaminan pribadi sebagai bentuk dominan dari pemegang saham, perseroan beroperasi dengan tidak semestinya. ${ }^{53}$ Kedua, kegiatan tersebut diterapkan karena melanggar hukum atau tindakan kriminal. Kegiatan yang melawan peraturan perseroan, seperti aktivitas perseroan berskala besar, tapi modal sangat kecil, perseroan dibentuk secara khusus untuk melakukan aktivitas berbahaya tanpa pengesahan resmi. ${ }^{54}$ Ketiga, hubungan induk perusahaan dengan anak perusahaan, dimana induk perusahaan tidak hanya bertanggung jawab sebagai entitas hukum, tapi juga bertanggung jawab jika ketiga elemen ini terpenuhi. Elemen tersebut, yaitu 1) Induk perusahaan mengontrol anak perusahaan 2) Induk perusahaan menggunakan control untuk melakukan fraud, penipuan, atau tindakan curang lainnya 3) terdapat kerugian sebagai hasil dari melanggar kewajiban. 55

Philip Knutsson, 'Piercing the Corporate Veil (Limits of Limited Liability)' (Thesis In Association Law, 30 HE credits, Faculty of Law, Stockholm University 2018) 16.

Ibid.

Presser, Piercing the Corporate Veil (Thomson Reuters 2006) 18-19.

Munir Fuady, Doktrin-Doktrin Modern Dalam Corporate Law Dan Eksistensinya Dalam Hukum Indonesia (Citra Aditya Bakti Bandung 2010) 250.

$54 \quad$ Ibid.

55 Ibid. 


\section{Penerapan Alter Ego Kaitannya Dengan Pertanggungjawaban Pemegang Saham Dalam PT Di Indonesia}

Pada tahun 2008, suatu institusi keuangan, PT Bank Century, jatuh ke dalam krisis keuangan, membuat bank tersebut dan afiliasinya, PT Antaboga Delta Sekuritas, tidak dapat untuk mengembalikan uang konsumen. Mahkamah Agung, menyatakan bahwa Robert Tantular dipenjara selama sembilan tahun untuk pelanggaran atas hukum perbankan dengan mencampuri kegiatan bank dan penggelapan dana. Sampai saat ini, para customer Antaboga masih belum mendapatkan tabungan mereka. ${ }^{56}$

PT Antaboda Delta Sekuritas sebagai anak perusahaannya PT Bank Century Tbk, pada awalnya merupakan agen penjual produk investasi. Banyaknya klien bank yang dibujuk untuk menaruh tabungan mereka ke Antaboga, diketahui atas pengaruh Robert Tantular, salah satu dari pemegang saham dominan. Kemudian, hasil investigasi menemukan bahwa produk tersebut tidak pernah didokumentasikan dalam catatan keuangan maupun dalam list produknya. Bank tidak pernah memungut biaya apapun terkait kontribusinya dalam menjual discretionary fund. Lebih khusus lagi, joint receipt antara Century dan Antaboga pada awalnya dikeluarkan untuk pembayaran pelanggan. Namun, di akhir tahun 2008, resi tersebut berubah, tapi tidak dengan nama Bank Century. Bank Century juga tidak pernah memiliki lisensi untuk menjual discretiony fund dan produk itu sendiri tidak pernah disetujui oleh manajer investasi. ${ }^{57}$

Apabila dihubungkan dengan doktrin PCV dalam Pasal 3 UUPT 2007, kasus ini seharusnya dapat dibuktikan dengan indikator alter ego. Dilihat dari penjelasan kasus di atas, Robert Tantular selaku pemegang saham dominan di perusahaan melakukan tindakan yang seakan-akan merupakan tindakan perusahaan dengan mempengaruhi klien bank untuk menaruh tabungan mereka ke Antaboga. Dia bersama dengan pemegang saham dominan lainnya juga bertanggung jawab atas penjarahan dengan total Rp. 1,38 triliun yang merupakan hasil penipuan yang mereka salurkan. ${ }^{58}$

Pengaplikasian dari doktrin PCV dapat diselesaikan dalam kasus, seperti penipuan, modal yang tidak memadai, kegagalan dalam memenuhi formalitas pembentukan perseroan, dan penyalahgunaan wewenang dalam perseroan sebagai hasil dari dominasi satu atau lebih pemegang saham. Dengan tambahan, doktrin PCV juga dapat dipaksakan untuk kasus seperti menghindari kewajiban hukum, melanggar kewajiban fidusia, dividen yang tidak dibayar atau pembayaran dividen yang berlebihan kepada pemegang saham, dan pemegang saham mayoritas yang menggunakan jaminan perorangan untuk dirinya sendiri untuk menanggung kewajiban dari perseroan. Faktor lain yaitu mengenai distribusi dana perusahaan oleh pemegang saham yang dominan, seperti contoh, Kasus Bank Century di atas. 59

56 Astrid Emmeline Kohar, 'Piercing the Corporate Veil: A Comparative Study of The Doctrine Under American and Indonesian Laws' (2012) 1 (1) Juris Gentium Law Review 121, 130.

Ibid.

Kohar (n 56) 130.

Wahyu Wiriadinata, 'Masalah Penyidik dalam Tindak Pidana Jasa Keuangan di Indonesia (Investigaor Problem in Crime Financial Services in Indonesia)' (2012) 9 (3) Jurnal Legislasi Indonesia 395, 400. 
Penipuan tampaknya telah menjadi penuntun di bawah alter ego. Selanjutnya, penggugat tidak hanya yang harus membuktikan bahwa perseroan tersebut digunakan secara tidak sah, dia juga harus membuktikan pula bahwa perseroan tersebut berfungsi di bawah kekuasaan, kendali dan untuk kepentingan pihak yang dominan. ${ }^{60}$ Clark dalam bukunya, menjelaskan bahwa ada three tier test yang biasanya digunakan oleh pengadilan ketika ada yang memohonkan alter ego ${ }^{61}$, yaitu:

1. Kontrol, tidak hanya mayoritas atau control saham penuh, tapi dominasi penuh, tidak hanya terhadap keuangan, tetapi juga terhadap kebijakan dan praktik bisnis sehubungan dengan transaksi yang diserang sehingga pada saat entitas perseroan untuk transaksi ini tidak memiliki pikiran yang terpisah, ia memiliki kemauan atau keberadaannya sendiri;

2. Kontrol tersebut harus digunakan oleh tergugat untuk melakukan penipuan atau kesalahan, untuk melakukan pelanggaran terhadap undang-undang atau hukum positif lainnya, atau ketidakjujuran atau tindakan tidak adil yang bertentangan dengan hak hukum penggugat;

3. Kontrol dan pelanggaran di atas harus secara langsung menyebabkan kerugian yang tidak adil yang dikeluhkan oleh penggugat.

Menurut Clark, terdapat bagian kedua dari test tersebut yang mana memegang faktor penentu untuk aturan alter ego. ${ }^{62}$ Satu dari prinsip yang diakui oleh UUPT 1995 maupun UUPT 2007 yaitu konsep dari PCV, yang mana dinyatakan dalam Pasal 3 pada kedua undang-undang tersebut. Itu merupakan prinsip hukum yang mengangkat pertanggungjawaban terbatas perseroan, yang mana menyebabkan pemegang saham bertanggung jawab secara pribadi atas kewajiban perseroan. Sayangnya, prinsip tersebut tidak pernah dieksekusi pada praktiknya di negara ini. Kasus usaha bisnis yang buruk seperti kasus Bank Century justru diselesaikan dengan hukum pidana tanpa menyadari bahwa terdapat doktrin PCV melalui penerapan alter ego. ${ }^{63}$ Pernyataan di atas sejalan dengan pendapat Sulistiowati, yang menyatakan bahwa sampai tahun 2012 belum ada suatu kasus yang mendasarkan putusan berdasarkan ketentuan Pasal 3 ayat (2) UUPT 1995 maupun Pasal 3 ayat (2) UUPT 2007. Hal ini menunjukkan bahwa pengimplementasian doktrin PCV di Indonesia sangatlah rendah, yang mana sangatlah mengecewakan, terlebih dalam UUPT sendiri sudah mengenal doktrin tersebut. 64

Dilihat dari Kasus Bank Century di atas, seharusnya Robert Tantular dan para pemegang saham yang lain juga dapat digugat secara perdata oleh para nasabah bank dengan dasar hukum, yaitu Pasal 3 ayat (2) UUPT 2007 dan bertanggung jawab secara pribadi atas tindakan yang dilakukannya. Namun, pada kenyataannya, pasal tersebut tidak digunakan karena hanya berfokus pada tindakan pidananya saja. Maka, dari kasus tersebut dapat dilihat bahwa Pasal 3 ayat (2) UUPT 2007 seperti pasal kosong yang mana tidak digunakan dalam

60 Cathy S. Krendl and James R. Krendl, 'Piercing the Corporate Veil: Focusing on The Inquiry' (1978) 55 (1) Denver Law Journal 3.

Robert Charles Clark, Corporate Law (Little Brown United Kingdom 1986) 37.

Ibid,. 38.

Kohar (n 56) 123.

Ibid., 124. 
prakteknya. Di Indonesia, sebenarnya UUPT sekalipun dapat dijadikan landasan hukum untuk memberlakukan tanggung jawab perdata pada pemegang saham, yaitu dengan cara pihak ketiga yang dirugikan karena tindakan pemegang saham tersebut mengajukan gugatan perdata kepada pemegang saham tersebut untuk bertanggung jawab secara penuh dengan dasar hukum Pasal 3 ayat (2) UUPT 2007.

Kasus lain yang dapat dijadikan contoh adalah kasus Bantuan Likuidasi Bank Indonesia (BLBI). BLBI yang semula bertujuan sebagai dana talangan (bail out) untuk kebutuhan dana nasabah malah diselewengkan pemilik bank untuk berbagai keperluan seperti membayar hutang perusahaan, menambah modal perusahaannya di luar negeri (termasuk capital flight), spekulasi valas di bursa saham, bahkan meminjamkan dana BLBI kepada bank-bank swasta lainnya yang masih membutuhkan dana talangan tambahan. Untuk mengatasi hal tersebut, Presiden Soeharto menetapkan Keputusan Presiden Nomor 27 Tahun 1998 tentang Pembentukan Badan Penyehatan Perbankan Nasional (BPPN) yang mempunyai tugas, yaitu65

1. Melakukan pengadministrasian jaminan yang diberikan Pemerintah pada bank umum.

2. Melakukan pengawasan, pembinaan, dan upaya penyehatan termasuk restrukturisasi bank yang oleh BI dinyatakan tidak sehat.

3. Melakukan tindakan hukum lain yang diperlukan dalam rangka penyehatan bank yang tidak sehat.

Seiring dengan keberadaan BPPN, jumlah BLBI pada akhir 1998 telah mencapai angka lebih dari Rp 140 Triliun. Bahkan pada April 1998 terjadi rush besar-besaran. Sementara bank-bank penerima BLBI mulai menunjukkan sikap non-kooperatif dengan tidak membayar bunga BLBI dan cicilan pokoknya. Keadaan ini memaksa Pemerintah yang harus menanggung sebagian jumlah BLBI, akhirnya membebankan lagi kepada masyarakat melalui APBN. Sedangkan tanggung jawab BI hanya Rp 24,5 Triliun sehingga mengakibatkan selisih atas hasil penjualan asset-asset yang dikuasai BPPN juga harus ditanggung oleh APBN. 66

Untuk mengatasi itu semua maka pada September 1998 BPPN melakukan suatu terobosan baru dalam rangka Penyelesaian Kewajiban Pemegang Saham (PKPS). Penyelesaian dilakukan melakukan jalur perdamaian (out of court settlement) karena dirasakan lebih efektif dan efisien dibandingkan dengan penggunaan jalur pengadilan (court settlement). Instrumen penyelesaian hutang antara pemegang saham pengendali bank penerima BLBI (debitor/obligor) itu adalah Master Settlement and Acquitition Agreement (MSSA) dan Master Refinancing and Note Issuance Agreement (MRNIA). ${ }^{67}$

MSAA adalah agreement yang ditandatangani oleh pemegang saham bank penerima BLBI dan pelanggar BMPK (Batas Maksimal Pemberian Kredit) apabila asset yang diserahkan dan atau dimiliki oleh pemegang saham pengendali dianggap cukup untuk melunasi seluruh hutang atau kewajibannya. Sedangkan, MRNIA adalah agreement yang ditandatangani oleh pemegang saham bank penerima BLBI yang dianggap tidak cukup untuk menutup seluruh kewajibannya

65 Tri Widya Kurniasari, 'MSAA dan MRNIA Bagi Recovery Dana BLBI: Sebuah Jalan Keluar Atau "Jalan Untuk Keluar"' (2006) 8 (1) Jurnal Masyarakat dan Budaya 43, 49.

$66 \quad$ Ibid., 50.

67 Ibid. 
sehingga mereka harus memberikan jaminan pribadi (personal guarantee). Hal inilah yang di kemudian hari menjadi kontroversi dan pernah digugat oleh ahli hukum Kartini Mulyadi dan Fred Tambunan yang menilai adanya diskriminasi terhadap para debitor BLBI.68

Penggunaan MSAA/MRNIA merupakan keputusan Pemerintah yang didasarkan pada pertimbangan-pertimbangan meskipun tidak memiliki dasar hukum. Namun BPPN dan Pemerintah memandang MSAA/MRNIA merupakan instrument perdata yang tunduk pada hukum perdata positif, yaitu Pasal 1338 KUHPerdata sehingga agreement itu sendiri menjadi undang-undang bagi penandatangannya (asas pacta sunt servanda). ${ }^{69}$

Dilihat dari alurnya, maka MSAA/MRNIA sebagai akibat dari penyaluran BLBI yang menjadi penyebab terjadinya BMPK. Setelah dialihkan oleh BI ke BPPN terjadilah subrogasi terhadap bank dan setelah dialihkan maka tagihan BPPN kepada Group Company atau pemegang saham pengendali (PSP). PSP inilah yang menandatangani agreement sesuai jumlah asset yang dijaminkan. Dalam melaksanakan agreement ini, BPPN membentuk holding company. Holding Company ini melakukan penjualan asset dan hasilnya akan dihitung sebagai recovery. Secara garis besar, kewajiban pemegang saham dalam MSAA hanya sebatas pernyataan dan jaminan yang disepakati dengan Pemerintah, dalam hal ini diwakilkan oleh BPPN. Sedangkan dalam MRNIA kewajiban pemegang saham sampai dengan jaminan pribadi atau melalui mekanisme personal guarantee. ${ }^{70}$

Disamping pelaksanaan MSAA/MRNIA yang belum optimal, namun hal ini cukup menarik, dimana dalam mengembalikan dana BLBI, Pemerintah melalui BPPN membuat terobosan dengan mengadakan perjanjian dengan Pemegang Saham Pengendali. Pemerintah memandang dana BLBI pada kenyataannya tidak digunakan dengan bijak oleh bank yang menerimanya. Menurut hasil penyidikan Kejaksaan, justru dana tersebut diselewengkan untuk kegunaan membayar hutang perusahaan, menambah modal perusahaannya di luar negeri, spekulasi valas di bursa saham, bahkan meminjamkan dana BLBI kepada bank-bank swasta lainnya yang masih membutuhkan dana talangan tambahan. ${ }^{71}$ Dapat dilihat bahwa penyelewengan dana BLBI yang dilakukan oleh PSP tersebut sudah termasuk tindakan yang menjadi pengecualian pada Pasal 3 ayat (2) UUPT 2007, yang mana PSP telah seenaknya menggunakan perusahaan untuk kepentingan pribadinya. Atau dengan kata lain, PSP telah terindikasi melakukan alter ego terhadap perusahaannya.

Dari kasus ini dapat dilihat bahwa sebenarnya Pemerintah melalui BPPN sudah menerapkan Pasal 3 ayat (2) UUPT 2007 kepada para pemegang saham bank tersebut. Pemerintah telah meminta pertanggungjawaban hingga harta pribadi kepada Pemegang Saham yang secara nyata telah menggunakan perusahaannya sebagai alter ego nya dengan mengadakan perjanjian MSAA/MRNIA tersebut. Dari sini dapat disimpulkan selain dapat meminta pertanggungjawaban pemegang saham melalui gugatan perdata atau melalui pengadilan, penyelesaian di luar pengadilan pun dapat dilakukan, yaitu dengan mengadakan perjanjian seperti

$$
\begin{aligned}
& \text { Ibid., } 52 . \\
& \text { Ibid. } \\
& \text { Ibid., } 53 . \\
& \text { Ibid., } 49 .
\end{aligned}
$$


MSAA/MRNIA dengan para pemegang saham yang terindikasi menjadikan perusahaannya sebagai alter ego.

\section{Pertanggungjawaban Mantan Pemegang Saham Hingga Harta Pribadi Jika Terbukti Melakukan Alter Ego Saat Masih Menjadi Pemegang Saham}

Selanjutnya, bagaimana pertanggungjawaban mantan pemegang saham, jika ketika dirinya masih berstatus sebagai pemegang saham terbukti melakukan alter ego?. Justru dengan penerapan alter ego sebagai indikator adanya doktrin PCV, hal ini dimaksudkan untuk menjangkau pertanggungjawaban pemegang saham sampai dengan ketika terjadi keadaan pemegang saham yang bersangkutan kemudian tidak lagi menjadi pemegang saham, misalnya dengan cara menjual sahamnya kepada pihak ketiga. Sekalipun saham miliknya telah dijual, namun dalam kenyataannya sebagai mantan pemegang saham mayoritas, mantan pemegang saham ini bisa tetap saja menjadi beneficial owner atau pemilik manfaat atau pengendali secara tidak langsung.

Dalam keadaan sedemikian dengan diterapkannya indikator alter ego kepada mantan pemegang saham, maka dirinya tetap dapat dimintai pertanggungjawaban atas perbuatan alter ego-nya dengan menyalahgunakan Perseroan untuk kepentingan pribadinya sehingga merugikan Perseroan itu sendiri atau merugikan pihak ketiga atau kreditur Perseroan. Mantan pemegang saham dengan alter egonya ini masih tetap saja mampu mengendalikan perseroan untuk kepentingan dirinya. Jika penerapan doktrin PCV masih dalam kerangka memenuhi pelanggaran Pasal 3 ayat (2) UUPT 2007 saja, maka aturan tersebut hanya dapat menjangkau pemegang saham existing, namun, dengan adanya penerapan indikator alter ego justru dapat menjangkau pertanggungjawaban hingga kepada mantan pemegang saham yang melakukan alter ego sampai merugikan Perseroan itu sendiri atau pihak ketiga atau kreditur Perseroan.

Sangat tidak adil, jika pada saat ia masih berstatus sebagai pemegang saham memanfaatkan Perseroan secara individu dengan alter ego-nya ternyata merugikan Perseroan atau kreditur Perseroan, kemudian dirinya keluar dari kedudukannya sebagai pemegang saham untuk menghindari pertanggungjawaban terhadap kreditur Perseroan. Dengan adanya indikator alter ego, mantan pemegang saham tetap saja dapat digugat untuk mempertanggungjawabkan perbuatan alter ego-nya yang merugikan pihak ketiga atau kreditur Perseroan tersebut. Pada tataran praktek, alter ego sangat mungkin dilakukan oleh mantan pemegang saham mayoritas dalam Perseroan. Oleh sebab itu ia tetap dapat dimintai pertanggungjawaban atas perbuatannya sewaktu dirinya masih menjadi pemegang saham. Bahkan sebagai mantan pemegang saham mayoritas, bisa saja ia tetap menjadi beneficial owner atau pemilik manfaat.

Dengan penerapan indikator alter ego, ia dapat dimintai pertanggungjawaban tidak hanya pada saat ia masih menjadi pemegang saham, tetapi juga ketika ia telah menjadi mantan pemegang saham namun tetap menjadi beneficial owner atau pemilik manfaat. Sejarah konglomerasi di Indonesia, menempatkan mantan pemegang saham mayoritas keluar dari kedudukannya sebagai pemegang saham dan beralih menjadi pemilik manfaat atau beneficial owner. Dalam PT Terbuka, Otoritas Jasa Keuangan dalam POJK No. 4/3/2021 telah membuat aturan yang 
mengharuskan pengungkapan identitas Pengendali Perseroan Terbuka baik langsung maupun tidak langsung. Pengendali tidak langsung jelas tidak akan tercantum namanya sebagai pemegang saham pada PT Terbuka, namun secara tidak langsung ia akan mengendalikan PT Terbuka tersebut. Pengendali tidak langsung inilah yang sering disebut Beneficial Owner atau Pemilik Manfaat. Dengan adanya alter ego sebagai indikator, ia akan dapat dimintai pertanggungjawaban hukum ketika dirinya masih menjadi pemegang saham dan memanfaatkan perseroan untuk kepentingan individu atau pribadi pemegang saham mayoritas tersebut.

\section{PENUTUP}

Berdasarkan pembahasan di atas, dapat disimpulkan bahwa pengaturan doktrin PCV terdapat dalam Pasal 3 UUPT 2007, di mana sebelumnya juga diatur dalam Pasal 3 UUPT 1995, yang pada intinya menyatakan bahwa pemegang saham hanya bertanggung jawab sebatas saham yang dimilikinya, namun terdapat pengecualian, yaitu pemegang saham harus bertanggung jawab secara pribadi apabila pemegang saham tersebut melakukan tindakan-tindakan sebagaimana diatur dalam Pasal 3 ayat (2) UUPT. Doktrin ini bertujuan supaya kedudukan mandiri perseroan sebagai badan hukum tidak disalahgunakan oleh para pemegang saham, direktur maupun dewan komisaris. Doktrin PCV sendiri dapat dikualifikasikan penentuannya berdasarkan beberapa indikator, salah satunya alter ego. Penerapan alter ego dapat dilihat dari beberapa tindakan tidak wajar yang dilakukan oleh perseroan, seperti mengontrol perseroan secara dominan, melakukan keputusan yang hanya untuk kepentingan pibadi, menipu pihak ketiga disaat melakukan transaksi, melakukan kegiatan bisnis yang beresiko tinggi namun memiliki modal yang kecil.

Di Indonesia sendiri, pengimplementasian doktrin PCV masih jarang sekali dieksekusi, seperti contoh pada kasus Bank Century, yang mana pemegang saham dominan sebenarnya dapat digugat secara perdata oleh Nasabah dengan menggunakan dasar Pasal 3 ayat (2) UUPT. Kasus tersebut dapat dibuktikan melalui penerapan alter ego sebagai indikator terhadap doktrin PCV karena tindakan pemegang saham dominan seolah-olah merupakan tindakan perusahaan untuk menghasut para klien untuk menempatkan tabungannya kepada Antaboga. Namun pada kenyataannya, penegak hukum pun tidak menggunakan doktrin tersebut untuk meminta pertanggungjawaban pribadi pemegang saham, melainkan hanya berfokus pada tindakan pidananya saja. Oleh sebab itu, dapat dikatakan bahwa Pasal 3 ayat (2) UUPT ini seperti pasal kosong karena pada prakteknya tidak digunakan. Padahal, Pihak Ketiga yang dirugikan karena tindakan pemegang saham yang melakukan alter ego dapat menggugat secara perdata dengan menggunakan dasar hukum Pasal 3 ayat (2) UUPT. Dengan begitu, akan ada putusan yang mendasarkan pertimbangannya pada Pasal 3 ayat (2) UUPT. Namun terdapat hal yang menarik dimana Pemerintah mengimplementasikan Pasal 3 ayat (2) UUPT dalam kasus BLBI. Pemerintah meminta pertanggungjawaban Pemegang Saham Pengendali sampai dengan harta pribadinya untuk melunasi dana BLBI yang dipinjamnya melalui perjanjian MSAA/MRNIA. Tindakan Pemerintah tersebut dapat pula dilakukan oleh pihak 
ketiga guna meminta pertanggungjawaban pemegang saham di luar pengadilan. Demikian pula penerapan alter ego sebagai indikator dapat dipakai sebagai alat untuk menjangkau pertanggungjawaban mantan pemegang saham atau beneficial owner atau pemilik manfaat, ketika pada saat menjadi pemegang saham dari suatu Perseroan menggunakan alter ego untuk merugikan Perseroan itu sendiri dan pihak ketiga atau kreditur Perseroan.

\section{DAFTAR REFERENSI}

\section{Buku}

Clark RC, Corporate Law (Little Brown United Kingdom 1986).

F Easerbrook and D Fischel, The Economic Structure of Corporate Law (Harvard University Press, United States 1991).

Fuady M, Doktrin-Doktrin Modern Dalam Corporate Law Dan Eksistensinya Dalam Hukum Indonesia (Citra Aditya Bakti Bandung 2010).

Harahap, Hukum Perseroan Terbatas (Sinar Grafika Jakarta 2009).

Khairandy R, Perseroan Terbatas Doktrin, Peraturan Perundang-undangan, dan Yurisprudensi (ed. Revisi, Kreasi Total Media Yogyakarta 2009).

Kraakman R, et al., The Anatomy of Corporate Law A Comparative and Functional Approach (Oxford University Press New York 2004).

Pettet B, Company Law (Pearson Education Limited 2005).

Pramono N, Hukum PT Go Public dan Pasar Modal (Andi Offset Yogyakarta 2013).

Prasetya R, Kedudukan Mandiri dan Pertanggungjawaban Terbatas Dari Perseroan Terbatas (Airlangga University Press Surabaya 1983).

Prasetya R, Perseroan Terbatas: Teori dan Praktik (Sinar Grafika Jakarta 2011).

Presser, Piercing the Corporate Veil (Thomson Reuters 2006).

Simanjuntak, Hukum Perdata Indonesia (Kencana Jakarta 2015).

Soemitro R, Penuntun Perseroan Terbatas Dengan Undang-Undang Pajak Perseroan (cet. 6, Eresco Jakarta 1979).

\section{Jurnal}

Berle AA, 'The Theory of Enterprise Entity' (1947) 47 (3) Columbia Law Review.

Bordwin M, 'Piercing the Corporate Veil' (1995) 84 (8) Management Review.

Budiono H, 'Arah Pengaturan Undang-Undang Nomor 40 Tahun 2007 tentang Perseroan Terbatas Dalam Menghadapi Era Global' (2012) 1 (2) Junral RechtsVinding.

Hunt S, 'Piercing The Corporate Veil' (1995) 13 (2) Paralegal Today.

Khairandy R, 'Perseroan Terbatas Sebagai Badan Hukum' (2007) 26 (3) Jurnal Hukum Bisnis.

Kohar AE, 'Piercing the Corporate Veil: A Comparative Study of The Doctrine Under American and Indonesian Laws' (2012) 1 (1) Juris Gentium Law Review. 
Krendl CS and Krendl JR, 'Piercing the Corporate Veil: Focusing on The Inquiry' (1978) 55 (1) Denver Law Journal.

Kurniasari TW, 'MSAA dan MRNIA Bagi Recovery Dana BLBI: Sebuah Jalan Keluar Atau “Jalan Untuk Keluar"' (2006) 8 (1) Jurnal Masyarakat dan Budaya.

Kurniawan, Tanggungjawab Pemegang Saham Perseroan Terbatas Menurut Hukum Positif' (2014) 26 (1) Mimbar Hukum.

Nugroho S, Nasution B, dan Sitompulc Z, 'Implementation of Alter Ego Shareholders and Their Responsibilities According to the 'Piercing the Corporate Veil' Doctrine in Indonesia' (2000) 11 (8) International Journal of Innovation, Creativity, and Change.

Rissy YYW, 'Doktrin Piercing the Corporate Veil: Ketentuan dan Penerapannya di Inggris, Australia, dan Indonesia' (2019) 4 (1) Refleksi Hukum: Jurnal Ilmu Hukum.

Sefriani, 'Status Hukum Aset Perusahaan Negara Dalam Hukum Internasional' (2012) 24 (3) Mimbar Hukum.

Sulistiowati, 'Doktrin-Doktrin Hukum Mengenai Tanggung Jawab Hukum dalam Perusahaan Grup' (2012) 31 (3) Hukum Bisnis.

Wahyuni VT, 'Kepemilikan Tunggal Badan Hukum Perseroan Terbatas' (2017) 8 (2) Jurnal Hukum Novelty.

Wardhana GP, 'Pertanggungjawaban Harta Pribadi Pemegang Saham Perseroan Terbatas di Indonesia' (2019) 12 (1) Arena Hukum.

Wiriadinata W, 'Masalah Penyidik dalam Tindak Pidana Jasa Keuangan di Indonesia (Investigaor Problem in Crime Financial Services in Indonesia)' (2012) 9 (3) Jurnal Legislasi Indonesia.

\section{Thesis}

Knutsson P, 'Piercing the Corporate Veil (Limits of Limited Liability)' (Thesis In Association Law, $30 \mathrm{HE}$ credits, Faculty of Law, Stockholm University 2018).

\section{Website}

Nindyo Pramono, 'Perbandingan Perseroan Terbatas di Beberapa Negara' (Karya Ilmiah Badan Pembinaan Hukum Nasional Kementerian Hukum dan Hak Asasi Manusia, November 2012) 19 < https://www.bphn.go.id/data/ documents/pk-2012-1.pdf > diakses pada 14 Desember 2020.

\section{Peraturan Perundang-Undangan}

Kitab Undang-Undang Hukum Perdata.

Kitab Undang-Undang Hukum Dagang.

Undang-Undang Nomor 40 Tahun 2007 tentang Perseroan Terbatas (Lembaran Negara Republik Indonesia Tahun 2007 Nomor 106, Tambahan Lembaran Negara Republik Indonesia Nomor 4756). 